\title{
Introduction to Oya Tuff
}

\author{
by
}

Takafumi SEIKI*

Key words: Oya tuff, Geological Characteristics, Engineering Characteristics, Underground quarry, History

\section{1 緒言}

大谷石(おおやいし)は，杤木県宇都宮市に産出する軽石 凝灰岩あるいは火山砕石凝灰岩である。平成 28 年(2016 年)5 月に日本地質学会によって，杤木県の石に，黄銅鉱 (鉱物)，木の葉石(化石)とともに制定され，県を代表する 石である. この石の地質的, 工学的特徵, 大谷石の石材 を切り出した後に生まれる採石地下空間の生まれる背 景とその工学的性質について紹介する.

\section{2 大谷石とは}

大谷石は, 栃木県宇都宮市の北西部の約 $7 \mathrm{~km}$ に位置す る栃木県宇都宮市大谷町(図 1) 吕中心に, 田下町, 田野 町などから，東西約 $4 \mathrm{~km}$, 東北約 $6 \mathrm{~km}$ の範囲に分布する 軽石凝灰岩あるいは水山採石凝灰岩の通称である。今か ら約 2 千万年前から 1 千 5 百万年前に海底火山の激しい 活動により, 溶岩, 軽石, 火山灰, 砂碩などが海底に堆 積してできた「軽石凝灰岩」で，埋蔵量は約 6 億トンと 推定されている。 その趣のある岩質, 色調から, 石塀, 石垣，門柱などをはじめとする住宅用石材に多く利用さ れている. 歴史的に約 1150 年前に使われていたことが 記録されているほど，昔から使われていた。 約 900 年前 の宇都宮城(宇都宮市役所のある場所)に初めて建設され たときに切り出されて用いられたことが記録に出てい る.また, 1620 年に宇都宮城の改築の際にも用いられた ように，地元杤木県では，古くから重宝されてきた.

それ以外にも，耐火性や防音効果に優れているため, 江戸時代から貴重な品物を保管する為の倉の建設など にも多く使用された. 大正 11 年(1922 年)に建築家フラ ンク・ロイド・ライトの設計により大谷石で建築された 旧帝国ホテルは，大正 12 年(1923 年)の関東大震災にお いて焼け残り, 大谷石はその耐火性, 而震性の優秀さが 認められ，第一級の建築資材として一躍脚光を浴びた。 近年では，加工技術の向上に伴い，デザインの多様性か ら店舗内外装や和風建築にも広く利用されている.

\section{$2 \cdot 1$ 大谷石の地質学的情報}

大谷町は標高 $200 \mathrm{~m}$ の丘陵地帯にあり, この地域の地 質は足尾帯に属し, 中・古生代のチャート・砂岩・頁岩 などから成る古代古第三紀の基盤岩, 大谷石層から成る 新三紀層，宝木硯層と北関東口ーム（宝木粘土層）から 成る第四紀の洪積層から構成されている.今から約 2,000 万年前, 日本列島が現在の位置に形成されつつある新生 第三紀中新世の前半に, 鹿沼丘陵, 半蔵山, 宇都宮北方

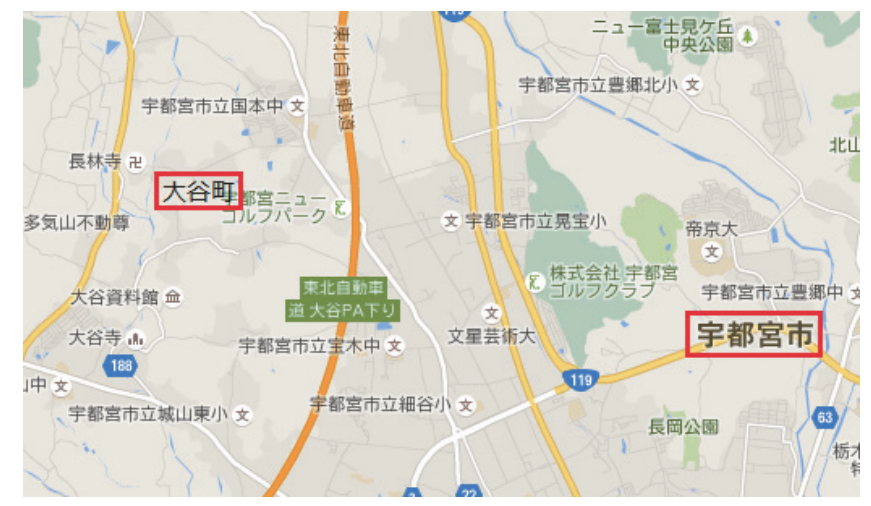

図 1 大谷町の位置 1$)$

の笠松山一宮山田で火山活動があり, 安山岩質溶岩類を 噴出した。 その後, 流紋岩質の海底火山の爆発により, 大規模な水中火砕流が大谷付近の湾を埋めて大谷石が 堆積し, それが凝固して現在の大谷石となった。 また, 杤木県内では, 類似の石材が多く産出している(表 1$)^{2)}$. また，大谷石の層序は，石材や地質との関連から整理さ れている(表 2$)^{2)}$.

大谷石の岩石としての基質は多量の浮石質ガラス, 斜 長石, 石英と少量の黒雲母角閃岩輝石で構成されている. 大谷石に斑点状に含まれる軟らかい褐色の「ミソ」と呼 ばれる部分は, 含水量の多い沸石およびモンモリロナイ 卜の粘土鉱物から成る少量の蛋白石鉄塩鉱物などの不 純物を含んでいるがその由来については諸説ある ${ }^{2)}$. 大 谷石は, 花崗岩などの硬岩と比較して重量が軽く, 柔ら かいため加工がしやすく, 耐火性, 防湿性に優れている. その一方で，大谷石は非常に風化の進行が早く6)，特に ミソ部分は劣化して久落しやすいため, これまで風化現 象による大谷石の劣化メカニズムについての研究 5)など が行われてきた。

\section{$\mathbf{2} \cdot \mathbf{2}$ 大谷石採石の歷史と有効利用}

大谷石は主に住宅, 倉庫(石蔵), 防火壁, 貼石, 石塀, 門柱，敷石，石垣，土止め石（擁壁）等，建築用材とし て使用されてきた ${ }^{2)}$. これら建築用材としての大谷石の 歴史は古く, 最も古いものに縄文時代の竪穴式住居の炉 石があり, 古墳時代では古墳石室に利用され, 鎌倉・室 町時代のものでは大谷寺の五輪塔, 国分寺の紫塚五輪塔

+ 原稿受理 平成29年5月22日 Received May 22, 2017 C2017 The Society of Materials Science, Japan

* 正 会員 宇都宮大学大学院工学研究科 干321-8585 宇都宮市陽東, Graduate School of Eng. Utsunomiya Univ. Yoto, Utsunomiya, Tochigi Pref.,321-8585, Japan. 
表 1 栃木県で産出する大谷石とその類似石について ${ }^{2)}$

\begin{tabular}{|c|c|c|c|c|c|}
\hline 石材名 & 地層名 & 産出地 & 岩 相 & 年 代 & 海成・陸成環境 \\
\hline $\begin{array}{c}\text { 大谷石 } \\
\text { (おおやいし) }\end{array}$ & 大谷層 & $\begin{array}{l}\text { 宇都宮市大谷町, } \\
\text { 田野町, 田下町 }\end{array}$ & 軽石凝灰岩 & $\begin{array}{l}\text { 中期中新世, } \\
\text { (約 } 1500 \text { 万年前) }\end{array}$ & 海成, 海中軽石流 \\
\hline 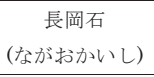 & 長岡層 & 宇都宮市長岡 & 軽石凝灰岩 & $\begin{array}{l}\text { 中期中新世, } \\
\text { (約 } 1500 \text { 万年前) }\end{array}$ & 海成, 海中軽石流 \\
\hline $\begin{array}{c}\text { 深岩石 } \\
\text { (ふかいわいし) }\end{array}$ & 深岩層 & 鹿沼市深岩 & $\begin{array}{l}\text { 白色, 塊状軽石凝灰岩, } \\
\text { 流紋岩質岩片を含む }\end{array}$ & $\begin{array}{l}\text { 中期中新世, } \\
\text { (約 } 1500 \text { 万年前) }\end{array}$ & 海成, 軽石流堆積物 \\
\hline $\begin{array}{c}\text { 岩舟石 } \\
\text { (いわふねいし) }\end{array}$ & 日向層 & 栃木市岩舟町 & 安山岩颀凝灰角磼岩 & $\begin{array}{l}\text { 前期中新世, } \\
\text { (約 } 1750 \text { 万年前) }\end{array}$ & 陸成層 \\
\hline $\begin{array}{c}\text { 茂木石 } \\
\text { (もてぎいし) }\end{array}$ & 茂木層 & 栃木県茂木町 & 軽石凝灰岩 & $\begin{array}{l}\text { 前期中新世, } \\
\text { (約 } 1700 \text { 万年前) }\end{array}$ & 陸域軽石流, 一部湖沼堆積 \\
\hline
\end{tabular}

表 2 大谷石の石材と地質的層序について ${ }^{2)}$

\begin{tabular}{|c|c|c|c|c|c|c|c|c|c|}
\hline \multicolumn{3}{|c|}{ 地質時代 } & \multicolumn{2}{|c|}{ 地層名 } & 層淮 Unit 名 & 岩石名 & 層の特徵 & 層厚 $(\mathrm{m})$ & 用途・産出化石 \\
\hline \multirow[b]{3}{*}{ 新 } & \multirow[b]{3}{*}{ 中 } & \multirow[b]{3}{*}{ 大 } & \multicolumn{2}{|l|}{$\mathrm{S} 1$ 層 } & S1 & $\begin{array}{l}\text { 泥岩, 細粒砂岩, } \\
\text { 凝灰岩質砂岩 }\end{array}$ & $\begin{array}{l}\text { 上部に円摩された白色軽石層(I 層)の二次堆積 } \\
\text { 物, 泥岩主体で生物攪乱構造有り。 }\end{array}$ & $80+$ & \\
\hline & & & \multicolumn{2}{|l|}{ II 層 } & II & 軽石凝灰岩 & $\begin{array}{l}\text { 細粒均質層とミソゾーンが互層, ミソ周辺に硬 } \\
\text { 質ガラス質部有り. }\end{array}$ & $17 \sim 70$ & 石材としては不良 \\
\hline & & & \multicolumn{2}{|l|}{ IV 層 } & IV & 軽石凝灰岩 & $\begin{array}{l}\text { ミソは中〜大, 基質は中〜粗粒. } 2 \mathrm{~mm} \text { の岩片入 } \\
\text { る. } 10 \sim 20 \mathrm{~mm} \text { の軽石多い. }\end{array}$ & $9 \sim 70$ & 石塀, 舗道用一般石材 \\
\hline \multirow[t]{2}{*}{ 第 } & \multirow[t]{2}{*}{ 新 } & 谷 & $\mathrm{V}$ 層 & 上部 & Vup & 軽石凝灰岩 & $\begin{array}{l}\text { 岩片を多く混入. ミソは全体に硬質. 泥岩に生 } \\
\text { 物擾乱の生痕有り. }\end{array}$ & 40 & 石塀, 舗道用一般石材 \\
\hline & & 層 & $\mathrm{V}$ 層 & 下部 & Vlo & $\begin{array}{l}\text { 軽石凝灰岩, 火山碩凝 } \\
\text { 灰岩, 凝灰質碩岩 }\end{array}$ & $\begin{array}{l}2 \sim 5 \mathrm{~mm} \text { 稀に数 } \mathrm{m} \text { の岩片や岩塊が入る. 無層 } \\
\text { 理でミソゾーン少ない. }\end{array}$ & 30 & 石材としては不良 \\
\hline \multirow{5}{*}{ 紀 } & & & \multicolumn{2}{|l|}{ VI 層 } & VI & 砂質凝灰岩 & 火山ガラス, 軽石, 砂を含む. 弱い層理有り. & 57 & 石材には不適 \\
\hline & & & \multicolumn{2}{|l|}{ S3 層 } & S3 & $\begin{array}{l}\text { 泥岩, 泥岩・砂質凝灰 } \\
\text { 岩互層 }\end{array}$ & $\begin{array}{l}\text { 泥岩に生物擾乱の生痕有り. 砂質凝灰岩は, 級 } \\
\text { 化を示寸. 砂質凝灰岩が優勢. }\end{array}$ & 11 & 石材には不適 \\
\hline & & & \multicolumn{2}{|l|}{ VII 層 } & VII & $\begin{array}{l}\text { 砂質凝灰岩, 溶結凝灰 } \\
\text { 岩, 凝灰質砂岩 }\end{array}$ & $\begin{array}{l}\text { 緑色の扁平な軽石を多く含む. 軽石は } 2 \text { } \\
40 \mathrm{~mm} . \text { 下部でラミナ発達し, 級化を示寸. }\end{array}$ & 21 & $\begin{array}{l}\text { 一部は田下石として } \\
\text { 採取 }\end{array}$ \\
\hline & & & \multicolumn{2}{|l|}{$\mathrm{S} 4$ 層 } & $\mathrm{S} 4$ & $\begin{array}{l}\text { 泥岩, 泥岩・凝灰質砂 } \\
\text { 岩互層 }\end{array}$ & $\begin{array}{l}\text { 泥岩に生物擾乱の生痕有り．単層の厚さ } 5 \sim ~ \\
10 \mathrm{~cm} \text {, 平行・コンボリュート葉理 }\end{array}$ & 30 & 石材には不適 \\
\hline & & & \multicolumn{2}{|l|}{ VIII 層 } & VIII & 溶結凝灰岩 & $\begin{array}{l}\text { 火山ガラス } 5 \sim 40 \mathrm{~mm} \text {, 軽石 } 2 \sim 5 \mathrm{~mm} \text {, 岩片 } 1 \\
\sim 2 \mathrm{~mm} \text { を含む. 火山ガラスは暗緑色で扁平. }\end{array}$ & $6+$ & \\
\hline
\end{tabular}

が知られる.また, 元和 6 年(1620 年)の宇都宮城の改築 では, 濠の土止めに大量の大谷石が使用された. 明治 32 年(1899年)から造営された旧日光田母沢御用邸の木造の 骨組みを支えるため, 約 3,700 本の大谷石が用いられ， 高さ $3 \mathrm{~m}$ を超える井筒組の基礎を構成していた.

この当時大谷町では大谷石を採石販売する商店や石 工たちの職人長屋が軒を並べ, 町のあちらこちらから石 切りの歌やトロッコを押寸職人の吹くラッパの音が聞 こえるなど，大変な賑わいを見せていた．採掘は明治時 代においては露天採掘が主流であったが，現在残ってい る空洞のほとんどは残柱式採掘である。また, 鉄道の発 達に伴い駅構内のホームや橋梁に利用され，東武鉄道の 東武宇都宮駅をはじめ, 多くのプラットホームを支え, 東武東上線の常盤台駅舎の外壁などにも大谷石が用い られた。 こうした中, 大正 12 年(1923 年)の関東大震災 の際に, 大谷石造の旧帝国ホテルが焼け残ったことから 大谷石の耐火性, 耐震性が見直され，利用に拍車がかか りパン釜やピザ釜等の石釜の構造物としても用いられ るようになった。戦前には宇都宮カトリック教会や宇都 宮聖公教会等教会建築にも大谷石が利用された.

高度経済成長に伴い宅地造成，工業団地造成が盛んに
なると大谷石が土止め用の石垣や石掘等に大量利用さ れ, 昭和 27 年頃から採石職人の手による掘削を機械化 する研究が始まり, 昭和 30 年(1955 年)には機械化され たシステムが完成したこともあり，昭和 30 年代には生 産量も年間 30 万トンを超える大谷石最盛期を迎えた。 しかしながら, 昭和 53 年(1978 年)に発生した宮城沖地 震により建築基準法が改正され，石塀には鉄筋を入れな くてはならないとする制限が課させられ，その用途は限 られるようになったことから, 需要に陰りが出始めた. さらに追い打ちをかけるように, 平成元年(1989 年)に大 規模な陷没事故が起き, 石材としての大谷石はイメージ ダウンにつながり, 採石する業者は減っていった. 現在, 採石後の地下空洞は，大小合わせて約 250 箇所あるとい われており, それらが数 10 年から 100 年以上にもわた って廃坑として放置されている。

一方, 地下空間利用という立場から, 昭和後半には 様々な利用方法が考えられていた。 その代表的なものと して, 音楽・演劇等のイベントホール, 岩盤内低温貯蔵 庫が挙げられる。前者の例として, 大谷資料館は, 昭和 53 年(1978)の開館以降, 地下空間を自然の舞台装置とし て演出した美術展や音楽コンサート等のイベントが開 
表 $3 \mathrm{XRD}$ 試験による大谷石を構成する鉱物の簡易定 量分析結果の重量比 $(\%)$

\begin{tabular}{|c|c|c|c|c|}
\hline 構成鉱物 & 試料(a) & 試料(b) & 試料( c ) & 試料(d) \\
\hline Clinoptilolite & 47.0 & 8.0 & 58.0 & 27.0 \\
\hline Quartz & 9.0 & 2.1 & 5.5 & 11.0 \\
\hline Cristobalite & 2.7 & 0.0 & 5.7 & 0.0 \\
\hline Tridymite & 0.0 & 0.0 & 0.0 & 1.0 \\
\hline Anorthite & 11.0 & 30.0 & 3.2 & 20.0 \\
\hline Albite & 16.0 & 0.0 & 8.0 & 7.0 \\
\hline Stilbite & 6.6 & 2.0 & 6.1 & 7.0 \\
\hline Stellerite & 6.0 & 0.0 & 13.0 & 0.0 \\
\hline Zeolite & 1.6 & 6.5 & 0.0 & 0.0 \\
\hline Muscobite & 0.0 & 51.0 & 0.0 & 15.0 \\
\hline Goethite & 0.1 & 0.0 & 0.0 & 0.0 \\
\hline Montmorillonite & 0.0 & 0.0 & 0.0 & 12.0 \\
\hline Unknown & 0.0 & 0.4 & 0.5 & 0.0 \\
\hline 合計 & 100.0 & 100.0 & 100.0 & 100.0 \\
\hline
\end{tabular}

表 4 乾湿繰り返し履歴がない新鮮な場合と乾湿履歴 がある大谷石の EDX による定量分析(原子数濃度 $(\%)$ )

\begin{tabular}{|c|c|c|}
\hline 構成元素 & 乾湿履歴なし & 乾湿履歴あり \\
\hline $\mathrm{O}$ & 64.71 & 63.16 \\
\hline $\mathrm{Na}$ & 0 & 0.84 \\
\hline $\mathrm{Mg}$ & 2.49 & 2.08 \\
\hline $\mathrm{Al}$ & 5.99 & 6.64 \\
\hline $\mathrm{Si}$ & 19.98 & 21.88 \\
\hline $\mathrm{Ca}$ & 1.06 & 0.82 \\
\hline $\mathrm{Fe}$ & 5.77 & 4.58 \\
\hline 合計 & 100 & 100 \\
\hline
\end{tabular}

(a) 垣根掘り 立坑

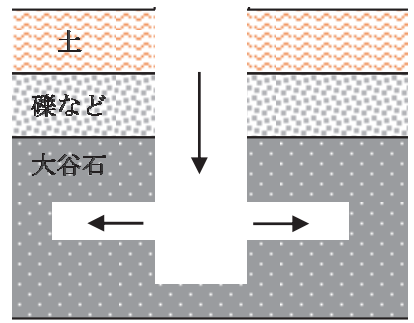

(b) 垣根掘り 立坑

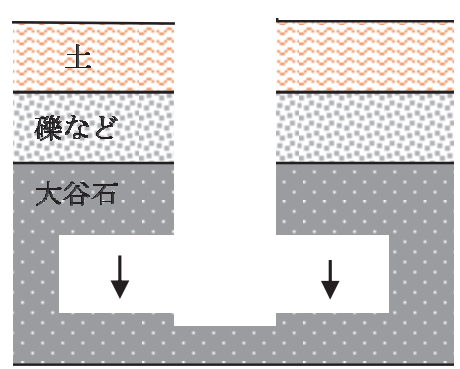

図 2 採石現場の形態
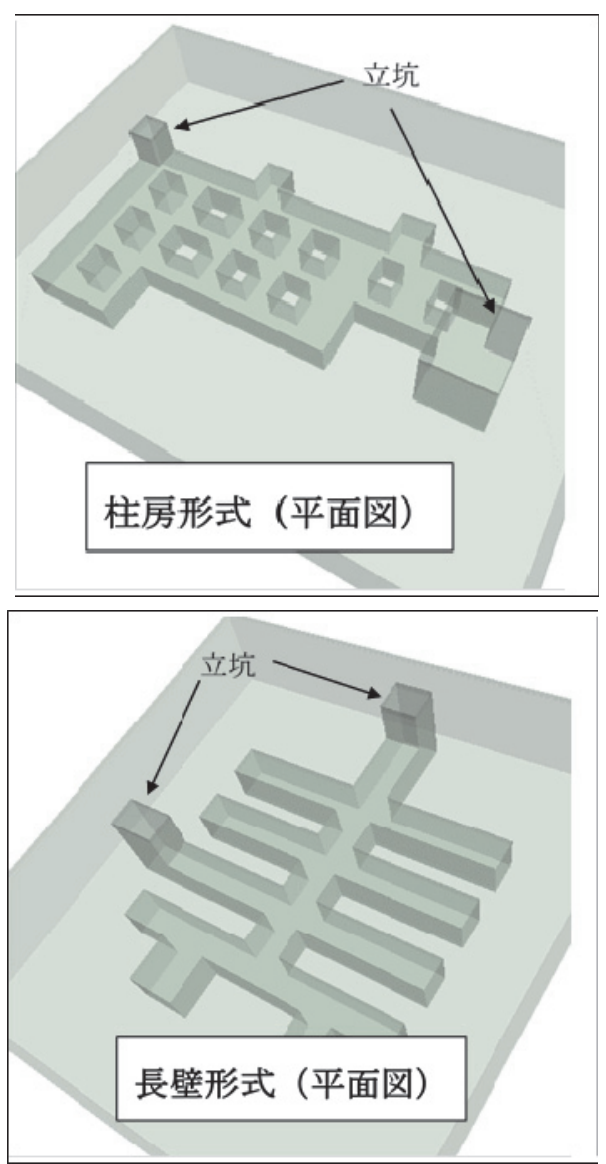

図 3 大谷石の地下採石場の形態

催された。後者に関しては, 近年の地球温暖化の進行に より環境負荷の低減が求められている事を受けて，地下 空間が有する恒温・恒湿性などの特徵を活かし，地上施 設に比較して環境負荷の低減を図ることができる貯蔵 施設等の地下空間利用について検討がされている。これ らの動向は後述する。

\section{$2 \cdot 3$ 大谷石の採石の歴史}

大谷石の採石方法には，平場掘りと垣根掘り(図 2)と いう 2 種類の掘り方がある. 平場掘りは下に掘り下げる 方法であり，手掘り時代の平場掘りで掘った跡には，横 線の切り跡が石面に見られるのが特徵である。もう一方 の垣根掘りは，横に掘っていく掘り方で，伊豆長岡の青 石の職人が，明治末から大正初期に大谷に伝えたと言わ れている．大谷石の地層は，きれいな石の層と，ミソと 呼ばれる茶色の粘土鉱物を多く含む石材として使えな い製品価值の低い石の層が水平に交互に堆積している ため, この層は掘らずに残し，製品価值の高い石の層だ けを掘ることが出来るため画期的な採石方法と言われ た．大谷石の採石には，この 2 つの採石方法を組み合わ せたいくつかの採石形態がある。採石形態は，大きく露 天掘りと坑内掘りの二つに分けられる.露天掘りは大谷 石採石の初期の形態で，地上に露出している採石しやす い石の部分を, 出来るだけ奥深く掘っていくため石壁が 斜めになる。一方坑内掘りは，地表が土などに覆われ， 石の層が地下深くにある場合などに用いられる採石形 態であり，大きく分けると「柱房式」と「長壁式」の採 掘方法(図 3)がある.柱房式採掘法は，一枚の層を碁盤目 状に掘っていき，碁盤目の区域を順次採掘していく方法 であり，比較的岩盤が丈夫な場所で行われることが多い. 


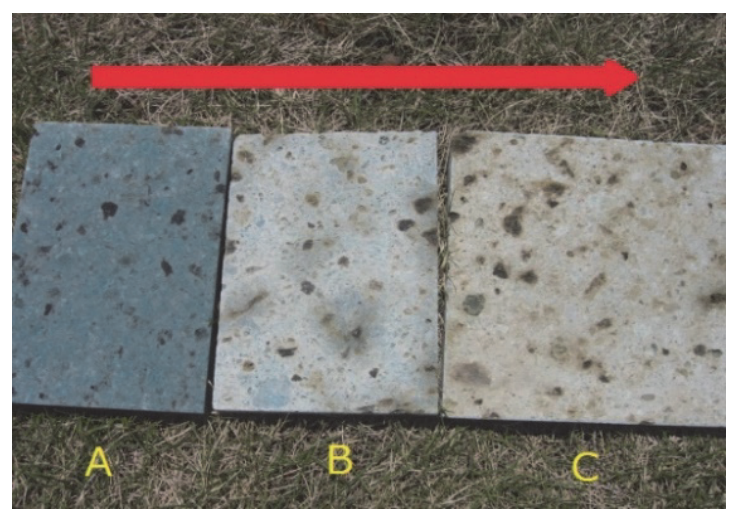

図 4 大谷石石材の変色の過程 $(\mathrm{A}$ : 採石後約 1 週間以内 $\mathrm{B}$ : 採石後約 1 力月 $\mathrm{C}$ : 採石後約 2 力月 $)^{4)}$

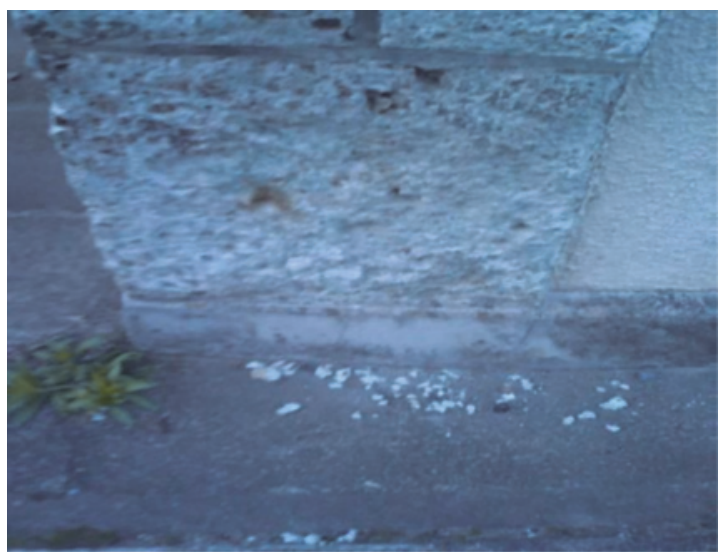

図 5 大谷石擁壁野白色の粉状に肌落ちする風化 ${ }^{3)}$

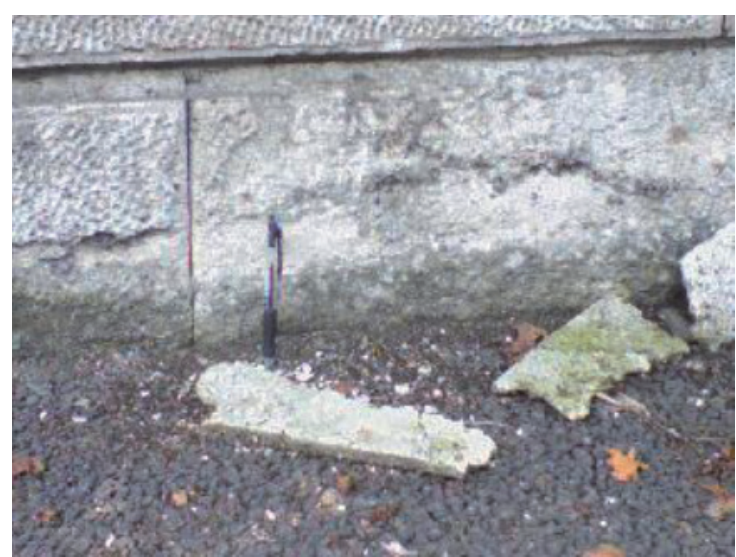

図6 大谷石擁壁の白色の粉状に肌落ちする風化 ${ }^{3)}$

長壁式採掘法は，炭層の傾斜の下側に大谷層に沿って片 盤坑道という水平な坑道を掘っていき, そこから櫛状に 削り取っていく方法である。この方法は，ドイツなど欧 米で広く採用された採掘法であり, 機械導入のしやすさ か機械導入のしやすさから日本でも戦後の主流となっ た.

\section{$2 \cdot 4$ 大谷石の工学的性質}

大谷石は，石材として使われるだけでなく，扱い易い 材料として, 岩盤工学の分野で多く実験が行われている。 新鮮な大谷石試料は, 採掘場所やその層序にもよるが, 平均吸水率 $30.16 \%$, 平均乾燥密度 $1.34 \mathrm{~g} / \mathrm{cm}^{3}$, 平均乾燥

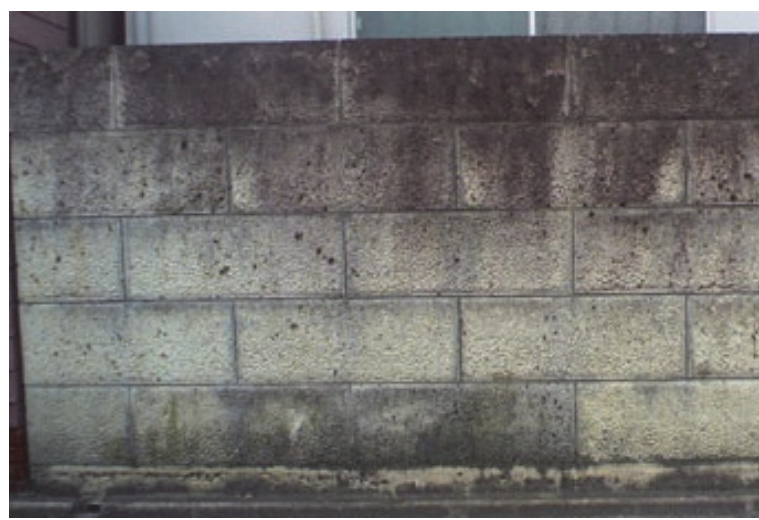

図 7 黒色に変色した大谷石

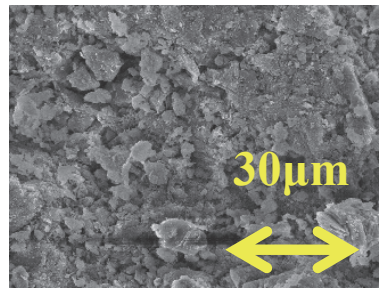

(a) 岩屑状構造

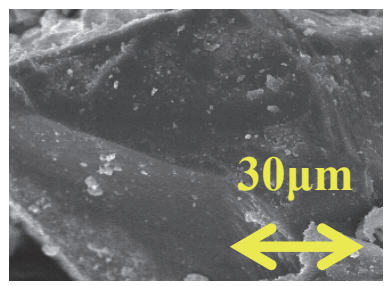

(c) 平滑構造

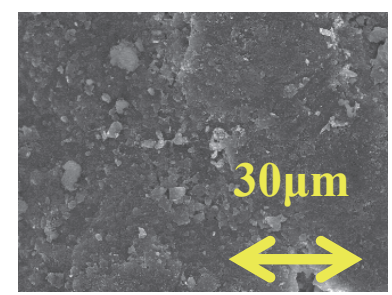

(b) 平坦構造

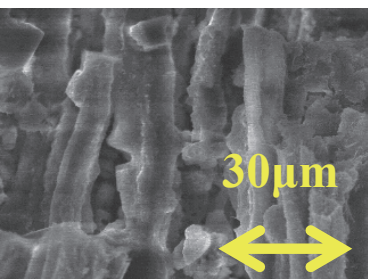

(d) 柱状構造
図 8 SEM 観察による大谷石表面の微視的構造 3 )

密度 $38.37 \%$ などの諸量を持つ. 大谷石表面の強度を針陥 入試験で簡易的に一軸圧縮強さとして求めると， 2.20 $\mathrm{MPa}$ である ${ }^{3)}$.ただし，これらの数值は，花崗岩などの 他の石材に比べて，ばらつきが大きい.

\section{$2 \cdot 5$ 大谷石の風化特性と工学的問題}

大谷石は，加工しやすい一方で，地上環境では風化の 進行が早く，それに伴う変色や強度低下，岩石表面の久 落がよく見られる。こうした風化による問題の予測を可 能に寸るためには，地上環境における化学的風化の影響 によって起こる変色や強度低下，鉱物組成の変化の関係 を捉え, 化学的風化による劣化状態を定量的に判断でき る指標を作成する必要がある. 大谷石は石質や使用方法 によっては風化し, 特に屋外の民家の壁面に用いられて いる大谷石は，その表面が脆弱化しやすい。雨や雪によ り大谷石が水分を吸水し, 吸水膨張を繰り返すことに伴 いその表面は次第に劣化すると予想され, 吸水膨張に伴 う大谷石表面の変化は, 表面劣化の原因に最も影響して いると考えられる。 大谷石の風化は，大谷石地下採石場 での観察および住宅の塀の観察に基づいて，表面が変色 (図4) 3 ) 寸るもの，浮いていて触ると簡単に剥がれて白色

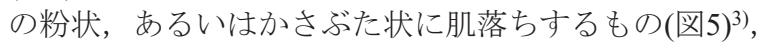
ある一定の深さで板状に肌落ちするものの3 種類に大別 される(図6 $)^{3)}$. これらの風化状況をつぎのように整理で きる。 


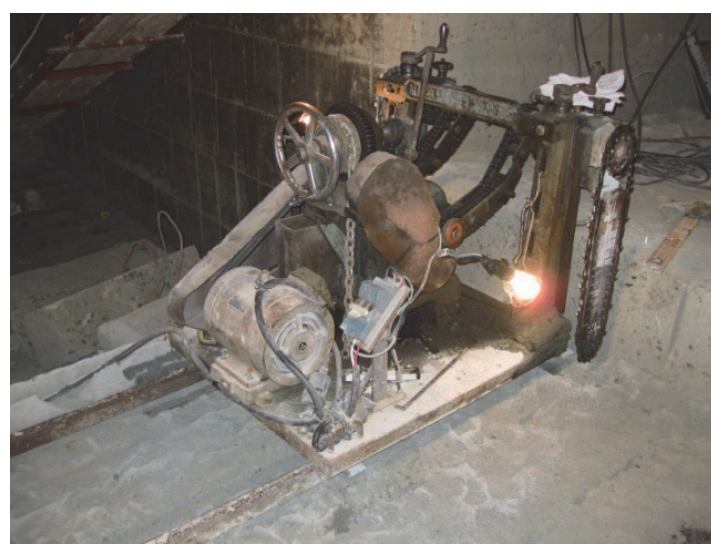

図 9 大谷石を切り出す裁断機

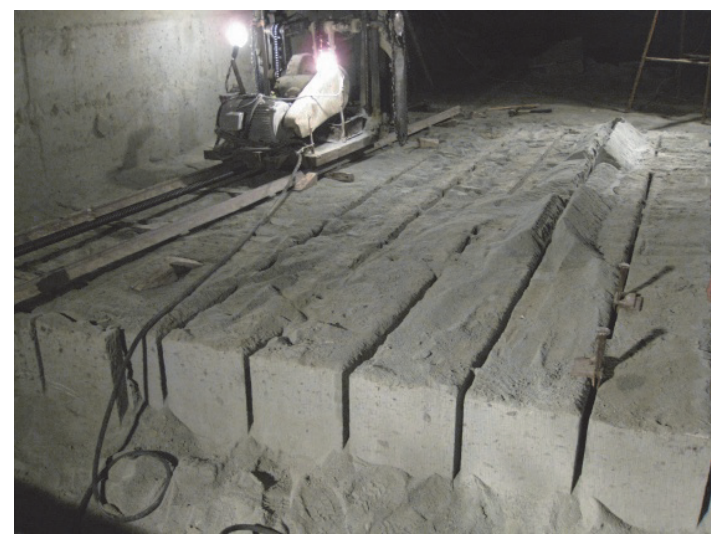

図 10 裁断機を用いた大谷石材の切削過程

1) 赤褐色に変色するもの

2) 白色粉状あるいはかさぶた状に肌落ちするもの

3）ある一定の深さで板状に肌落ちするもの

大谷石は風化に伴い，自然石であるために現場環境， 採石年数, 採石後の保存環境の条件によって変色の現れ 方が異なる。一般的に採石して間もない水分を含んだ湿 潤状態の大谷石は深青色であるのが，乾燥するに従って 淡緑色を呈し，時間の経過に伴い次第に赤褐色に変色す る傾向がある(図 4)。また外塀に用いられる大谷石の笠 石付近は雨の影響を受けることによって，黒く変色しや すいことが確認されている(図 7).

SEM によって観察された大谷石表面の構造を図 8 に 示す．柱状の構造は大谷石の内部で多く確認され，規則 性がなく様々な方向に結晶構造が向いていることから, Clinoptilolite(単斜プチロル沸石)上考えられる，岩屑状の 構造は大谷石表面で多く確認され, 柱状の Clinoptilolite の形状が崩れたものであると推測する。平滑な構造は EDX から $\mathrm{Si}$ (珪素) と $\mathrm{O}$ (酸素)で構成されていたため, Quartz(石英)である可能性が高い。平坦な構造は蒸留水, 雨水を塗布し静置した大谷石表面に多く確認された。こ れらの大谷石の微視的な構造と風化の関係について, 研 究が進められている ${ }^{3) ~ 5) . ~}$

\section{3 大谷石を切り出した後の空洞の利用}

大谷地域には，大谷石を切り出した(図 9-12)後の地 下採石場(以下，大谷採石地下空間)が，247 箇所にも登 り，平成元年(1989 年)に坂本地区において大規模な陥没 事故が発生し，さらにその後も大・中・小規模な陥没が

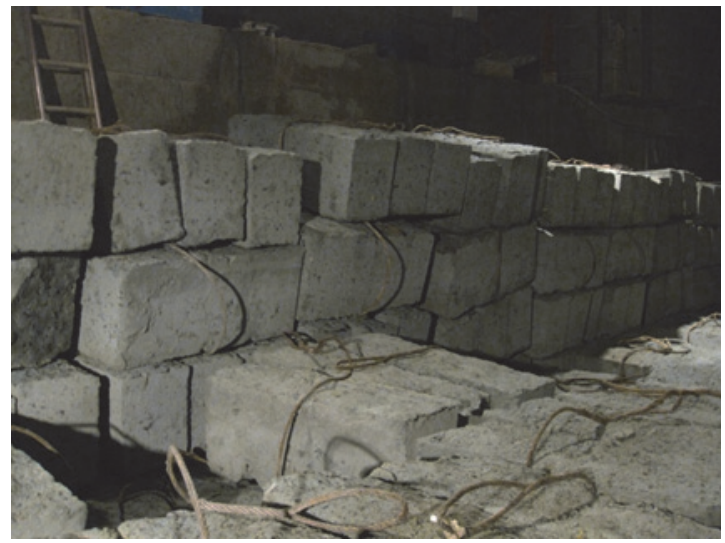

図 11 地上への搬出を待つ大谷石石材ブロック

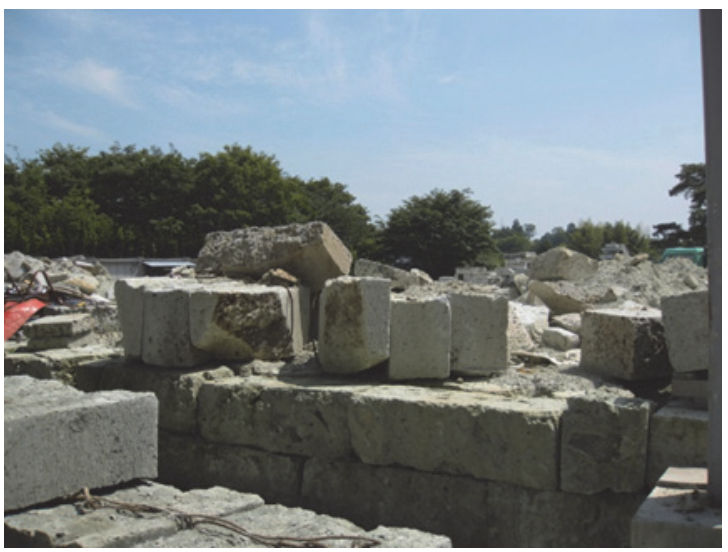

図 12 整形作業を待つ大谷石石材

発生した. これらのことから, 大谷の採石地下空間の危 険性が表面化し, 採掘後の地下空間の安定性の確保が近 年，特に重要視されてきており，大谷採石地下空間の有 効利用は，安全性の確保に基づいた利用者への安心の担 保が前提とされる. 近年, 地震時における大谷採石地下 空間の構造的な安定性や, 空洞内利用を促進することに 際して, 利用者への安心安全の確保と, その安全性を評 価する手法の確立が求められ, 研究が進められている 6) ９）。宇都宮市大谷地区では，地下空間の特性と大規模な 空間を活かした地下空間の利用が進められてきた。しか し, 様々な問題が浮上し, 撤退されたものもあり, 現在 は，貯蔵施設などの地下空間の利用が多く，観光客が減 少している現状にある。2000 年以降の大谷地域におけ るイベントを記す(文献 10) に追記)。このようなイベン 卜を通して，大谷石の需要を増やすとともに，大谷地域 の活性化が図られている.

2001 年 フェスタ in 大谷 2001 トワエモア・野外コン サートを開催.

2004 年フェスタ in 大谷 2004 Brown Blessed Voice「ゴ スペルコンサート」を開催.

2010 年 大谷石産業によって 32 年ぶりに新しい採掘 場が作られた。宇都宮市も，市内において住宅に 大谷石を使用した場合に費用を助成する制度を 制定.

2011 年 フェスタ in 大谷 2011 , 大道芸ショー，ナイト 


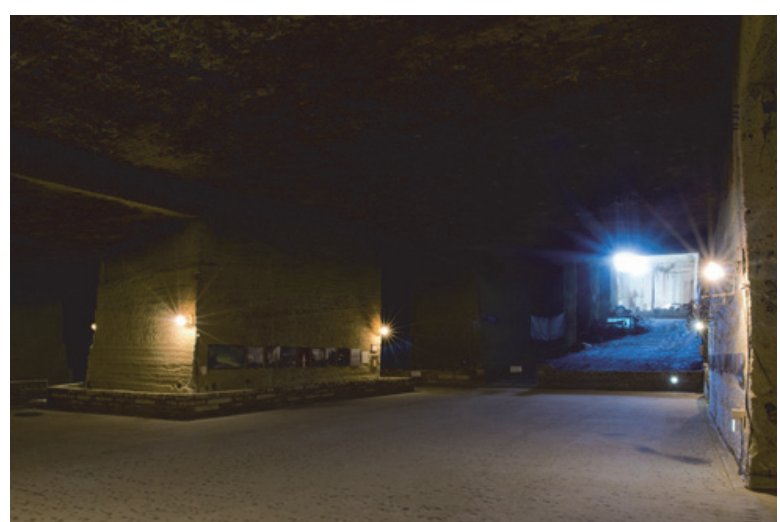

図 13 大谷採石地下空間とその有効利用例 10)

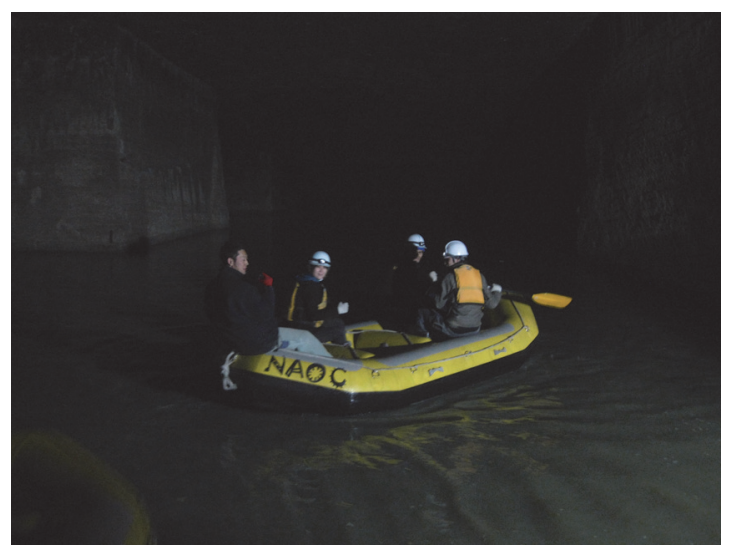

図 14 大谷採石地下空間の湛水を利用した有効利用 例

$$
\text { ジャズなどのイベントを開催. }
$$

2012 年 ネイチャープラネット(株)が大谷石採石場跡 地下空間の地下水が溜まっている箇所を利用し てカヤックやカヌーの体験プロジェクトを行い, 大谷地下リゾートプロジェクトのモニター調査 を実施 (図 14).

2012 年 フェスタ in 大谷 2012,「大谷石あかり展」ほ か様々なイベントを開催.

2012 年 宇都宮大学大学院教育学研究科の住環境・ま ちづくり研究室, 工学研究科の岩盤工学研究室, 宇都宮市等により Oya マチジクリ オイベントが 開催され, 大谷地区内外から約 100 名が参加.

2013 年 フェスタ in大谷 2013 , とちおとめ 25 のパフォ ーマンスなどのイベントを開催

2013 年 宇都宮大学大学院教育学研究科の住環境・まち づくり研究室, 工学研究科の岩盤工学研究室, 宇 都宮市等により OHYA UNDERGROUND SYMPOSIUM が開催され，大谷地区内外から約 200 名が参加.

2014 年 フェスタ in 大谷 2014 , 大谷石を自分で削るなど の加工体験, お囃子・和太鼓教室を開催

2014 年 2014 年ジャパンカップ大谷キャンプ, ジャパン カップサイクルロードレースと連携し, 大谷地域 においてキャンプイベントなどを開催

2015 年 フェスタ in 大谷 2015 , 大谷石ふれあい体験, 大 道芸バルーンショーなどのイベントを開催

2015 年 大谷資料館にて和の都〜宇都宮アートフェスタ を開催

\section{4 結言}

この解説記事では, 杤木県宇都宮市から産出し, 全国 で広く利用される石材である大谷石の地質学的, 工学的 観点からの特性に概略を紹介した。 大谷石は石材として, 長く使い続けるためには, 特に風化に伴う劣化や色調変 化が課題である.また, 大谷石を切り出したあとに生ま れる広大な採石地下空間の存在と, その有効利用のため 課題と最近の動向について紹介した. 日本の伝統文化を 支えてきた天然材料の一つである大谷石の特性やその 周辺の話題について理解を深めて頂けると幸いである.

\section{参 考 文 献}

1) Goole Map, URL : https://www.google.co.jp/maps/ (Referred May,2017)

2) Y. Aita, and T. Sakai, "Landscape and Geology of Oya tuff - Visit to History of Oya tuff, city of Stone Product Utsunomiya", Move Around Modern Architecture and Regional Culture with Oya tuff, pp.14-25, Utsunomiya Museum (in Japanese) (2017)..

3) H. Tateno, J. Iimura and T. Seiki, "Consideration to exfoliation for Oya tuff block with microscopic observation", Proc of the 14th Japan Symposium on Rock Mechanics, Kobe, No.103, 6p, JSRM, (in Japanese) (2017).

4) T. Seiki, A. Satoh, K. Kikuchi, "Weathering mechanisms and mechanical property changes of Oya tuff", Proc. of 12th ISRM Int. Congress on Rock Mech. Harmonising Rock Engineering and the Environment, Qian \& Zhou (eds), Beijing, China, pp. 821-824, (2011).

5) T. Orikasa, .K. Tada and T. Seiki, "Consideration on factor for colour tone change of Oya tuff based on colour tone reduction process", Proceedings. of 43th Rock Mechanics Symposium, JSCE, pp.42-47 (in Japanese) (2015).

6) T. Seiki, T. Chiba and T. Emori, Study on the Utility Assessment of Underground Quarry for Oya Tuff, Proc. of 1st International Symposium on Travertine, Denizli, Turkey, pp.245-255 (2005).

7) T. Seiki, H. Takaba and N. Hasegawa, "Some Considerations on seismic stability of Oya underground quarry", Proceedings. of 2014 ISRM Intl. Symp. 8th Asian Rock Mechanics Symposium Rock Mechanics for Global Issues - Natural Disasters, Environment and Energy -, ERD4-4, Sapporo, Japan, 9ps, (2014).

8) T. Inoue, A. Hayasaka, T. Abe and T. Seiki,"Consideration to long term utilization of Oya underground spaces based on evaluation of heat load", Proceedings of Underground Space Symposium, Vol.17, JSCE, pp.211-216, (in Japanese) (2012).

9) T. Inoue, T. Seiki, A. Hayasaka and D. Satoh, "Trial for utilization and maintenance of Oya underground spaces for environmental load reduction", Proceedings of Underground Space Symposium, Vol.18, JSCE, pp.165-170, (in Japanese) (2013).

10) Oya Musium Official HP, http://www.oya909.co. jp/ (Referred May, 2017) 